\title{
BRAND IMAGE: UPAYA MEMASARKAN PENDIDIKAN BAGI LEMBAGA YANG KURANG MAMPU BERSAING
}

\author{
Fajri Dwiyama ${ }^{1}$
}

\begin{abstract}
The focus of discussion in this paper is to provide an overview of efforts to market education to the community through the creation of a positive brand image for educational institutions. The background is government policies that give authority to educational institutions in managing their respective educational institutions so as to open the door to competition between educational institutions. Seeing the condition of competition that tends to be less healthy, encourages the writer to explain the concepts that can help educational institutions to be able to recognize the efforts made in marketing education, especially in terms of creating brand image. This becomes very important to be understood by the management of educational institutions, considering the brand image is the embodiment of an educational institution in the minds of consumers (students, students, students, and society) in assessing and dropping their choices to contribute to the chosen educational institution.
\end{abstract}

Keywords: Education, Brand Image, Marketing

\section{PENDAHULUAN}

Pengelolaan lembaga pendidikan yang kini bergeser dari sentralisasi menjadi desentralisasi menjadi cukup menarik. Lembaga pendidikan dituntut untuk mampu mengelola dan memasarkan sendiri produk pendidikan yang dimiliki. Meskipun pelaksanaan pendidikan terlihat seragam, namun disatu sisi telah terjadi perubahan yang cukup mendasar pada lembaga pendidikan khususnya dalam menarik minat calon peserta didik baru, serta masyarakat untuk berpartisipasi dan berkolaborasi dalam kegiatan pendidikan yang dilaksanakan oleh lembaga pendidikan.Tidak diragukan lagi, desentralisasi pendidikan sadar maupun tidak disadari telah membuka pintu persaingan antar lembaga pendidikan sederajat.

Ketika melihat lembaga pendidikan dari kacamata sebuah corporate, maka lembaga pendidikan adalah suatu organisasi produksi yang menghasilkan jasa pendidikan yang dibeli oleh para konsumen. Apabila produsen tidak mampu memasarkan hasil produksinya, dalam hal ini jasa pendidikan, disebabkan karena mutunya tidak dapat memuaskan konsumen, maka produksi jasa yang ditawarkan tidak laku. Artinya, lembaga pendidikan yang memperoses jasa pendidikan tidak mampu memuaskan user educations sesuai dengan

\footnotetext{
${ }^{1}$ Dosen Program Studi Manajemen Pendidikan Islam Institut Agama Islam Negeri (IAIN) Bone.
} 
kebutuhan pasar, bahkan lembaga pendidikan tersebut tidak akan berlaku untuk terus eksis. Berbeda dengan produk fisik, suatu layanan pendidikan tidak bisa disimpan. Ia diproduksi dan dikomsumsi secara bersamaan. Dampaknya terjadi pada sistem pemasaran terutama pada sisi permintaan. Jika permintaan stabil akan memudahkan penyediaan jasa pendidikan untuk melakukan persiapan, baik dari segi sarana prasarana maupun peralatan teknologi pendidikan lainnya. Tetapi jika permintaan fluktuatif, lebih sulit bagi penyedia jasa pendidikan untuk melakukan strategi pemasaran.Jasa pendidikan tidak bisa dilihat dan dirasakan oleh konsumen sebelum konsumen membeli atau mendapatkan penyedia jasa pendidikan secara langsung. Konsumen juga tidak bisa memprediksi apa hasil yang akan diperoleh dengan mengkonsumsi jasa pendidikan tersebut, kecuali setelah membelinya.

Mengingat keberadaan jasa pendidikan yang tidak berwujud, konsumen biasanya melihat tanda-tanda dari sesuatu yang bisa dilihat atau dirasakan untuk bisa menilai kualitas suatu jasa pendidikan. Mereka akan melihat kualitas dari para kualitas kinerja guru, tata usaha, dan karyawan sekolah, sarana prasarana sekolah, peralatan pendidikan sekolah, simbol-simbol yang digunakan sekolah, dan juga harga yang bisa mereka bayar pada sekolah. Dengan demikian, komponen lembaga pendidikan harus terus melakukan update pada sisi kompetensinya. Peningkatan kualitas pada sisi komponen lembaga pendidikan atau pada proses menunjuk pada peningkatan terus menerus yang dibangun atas dasar pekerjaan akan menghasilkan serangkaian output. Tujuan utama proses ini adalah untuk meningkatkan mutu pendidikan secara berkelanjutan, terus menerus, dan terpadu. Upaya peningkatan mutu pendidikan yang dimaksud tidak sekaligus, malainkan dituju berdasarkan peningkatan mutu pada setiap komponen pendidikan. ${ }^{2}$

Berdasarkan hal tersebut di atas, lembaga pendidikan sudah seharusnya menyadari akan kondisi tersebut, prinsipnya adalah dimana ada produk, pembeli, serta penjual, maka sudah pasti ada pasar, dan dimana ada pasar otomatis ada persaingan. Dengan menyadari keberadaan persaingan, sedapatnya lembaga pendidikan menyadari bahwa segala aktifitas yang terjadi pada lembaga pendidikan menjadi brand imange, dimana brand imange tersebut merupakan titik penilaian pertama bagi pembeli untuk melakukan tawar-menawar hingga akhirnya membeli jasa pendidikan yang dimiliki.

Begitu pentingnya posisi brand imange bagi keberlangsungan hidup sebuah lembaga pendidikan ditengah persaingan antara lembaga. Menyadari hal tersebut,

\footnotetext{
${ }^{2}$ Arbangki, Dakir, Umiarso, Manajemen Mutu Pendidikan, 2016, Jakarta: Prenadamedia, h. 117-118.
} 
memungkinkan sebuah lembaga pendidikan mampu bersaing dengan lembaga pendidikan lainnya.Namun fakta dilapangan menunjukkan bahwa sebagian besar lembaga pendidikan belum memahami hal tersebut sehingga mengalami kesulitan dalam persaingannya dengan lembaga-lembaga pendidikan swasta yang memiliki modal besar dan mempunyai brand image yang bagus serta telah dikenal masyarakat luas.

\section{PEMBAHASAN}

\section{Konsep Brand Image}

Istilah brand berasal dari kata brandr yang berarti "to brand", yaitu aktivitas yang sering dilakukan para peternak sapi di Amerika dengan memberi tanda pada ternak-ternak mereka untuk memudahkan identifikasi kepemilikan sebelum dijual ke pasar. ${ }^{3}$ Brand adalah indicator value yang anda tawarakan kepada pelanggan, brand merupakan asset yang menciptakan value bagi pelanggan dengan memperkuat kepuasan dan loyalitasnya, brand menjadi alat ukur bagi kualitas value yang anda tawarkan. ${ }^{4}$

Kotler berpendapat bahwa "a brand is a name, term, sign, symbol, or design or a combination of them, intended to identity the goods or servicesof one seller or group of seller and to differentiate them from those competitors." Sementara itu, de Chernatony dan McDonald berpendapat bahwa "brand is an identifiable product, service, person or place, augmented in such a way that the buyer or user perceives relevant, unique, sustainable added values which match their needs mostclosely." 5

Sedangkan menurut penuturan Aker, brand adalah nama dan atau simbol yang bersifat membedakan (seperti sebuah logo, cap atau kemasan) untuk mengidentifikasi barang atau jasa dari seorang penjual tertentu, serta membedakannya dari barang atau jasa yang dihasilkan para pesaing. Pada akhirnya, brand memberikan tanda mengenai sumber produk serta melindungi konsumen maupun produsen dari para pesaing yang berusaha memberikan produk-produk yang tampak identik. ${ }^{6}$

Dari beberapa pendapat di atas, dapat disimpulkan bahwa brand adalah simbolsimbol yang digunakan sebagai penanda atau identitas pembeda yang dimiliki oleh

\footnotetext{
${ }^{3}$ Andi Sadat, Brand Belief : Strategi Membangun Merek Berbasis Keyaninan, Jakarta: Salemba Empat, 2009, h. 18.

${ }^{4}$ Hermawan kartajaya, Hermawan Kartajaya On Brand Seri 9 Elemen Marketing, Bandung: Penerbit Mizan, 2007, h. 11.

${ }^{5}$ Ibid., h. 19.

${ }^{6}$ Susanto, Himawan Wijarnako, Power Branding (Membangun Merek Unggul dan Organisasi Pendukungnya Jakarta: PT. Mizan Publika, 2004, h. 6.
} 
lembaga sebagai wujud keberadaan sebuah lembaga. Brand pada lembaga pendidikan biasanya diwujudkan dengan lambang dan nama organisasi pendidikan yang bertujuan sebagai sebuah tanda pengenal.

Sedangkan Image terbentuk dari bagaimana lembaga melaksanakan kegiatan operasional yang mempunyai landasan utama pada segi layanan. Image juga terbentuk berdasarkan impresi dan berdasarkan pengalaman yang dialami seseorang terhadap sesuatu, sehingga membangun suatu sikap mental. Kotler menyatakan bahwa image konsumen yang positif terhadap suatu brand lebih memungkinkan konsumen untuk melakukan pembelian. Brand yang baik juga menjadi dasar untuk membangun citra lembaga yang positif. ${ }^{7}$ Menurut Kotler dan Keller, image (citra) adalah kepercayaan, ide dan kesan yang di pegang oleh seseorang terhadap sebuah objek. Sebagian besar sikap dan tindakan orang terhadap suatu objek dipengaruhi oleh image suatu objek. Menurut Buchari Alma adalah kesan, impressi, perasaan atau persepsi yang ada pada publik mengenai perusahaan, suatu objek, orang atau lembaga. ${ }^{8}$

Sedangkan Menurut Levitt mengatakan bahwa image is theimpression, feeling, the conception which the public has of a company or organization, a conditionally created of an object, person or organization. Artinya: image adalah merupakan sebuah apresiasi, perasaan yang ada pada publik mengenai perusahan atau lembaga, mengenai suatu objek, orang atau lembaga. Image ini tidak dapat dicetak seperti mencetak barang di pabrik, tetapi image ini adalah kesan yang diperoleh sesuai dengan pengetahuan, pemahaman seseorang tentang sesuatu. ${ }^{9}$

Image akan di perhatikan publik dari waktu ke waktu dan akhirnya akan membentuk suatu pandangan positif yang akan dikomunikasikan dari satu mulut ke mulut yang lain. Dalam kesibukan kita sehari-hari jangan melupakan keadaan fisik, keterampilan, fasilitas, kantor, karyawan dan yang melayani publik harus selalu dalam garis dengan satu tujuan memuaskan konsumen. Katakan pada mereka apa yang kita perbuat untuk menjaga agar mereka selalu puas, diperbaiki di masa yang akan datang. Image merupakan realitas, oleh

${ }^{7}$ Philip Kotler, Manajemen Pemasaran, Edisi Milenium, Jakarta: PT. Prehellindo, 2002, h. 625.

${ }^{8}$ Ibid. h. 607.

${ }^{9}$ Levitt, The Marketing Imagenation, London: The Free Press, 1983, h. 55. 
karena itu jika komunikasi pasar tidak cocok dengan realitas, ketidakpuasan akan muncul dan akhirnya konsumen mempunyai persepsi yang buruk terhadap image organisasi. ${ }^{10}$

Berbeda dengan brand, image lebih kepada pembentukan citra atau gambaran pada pikiran manusia sehingga mereka dapat memahami obyek yang digambarkan. Jika brand adalah simbol maka image adalah gambaran tertang simbol tersebut. Berdasarkan hal tersebut dapat disimpulkan bahwa brand image lembaga pendidikan adalah gambaran simbol-simbol yang digunakan oleh lembaga pendidikan. Brand image sebuah sembaga pendidikan berbeda-beda satu dengan lainnya, hal tersebut terbentuk dari proses penggambaran secara terus-menerus yang dilakukan lembaga pendidikan kepada publik.

\section{Masalah dalam Pemasaran Jasa}

Kotler mengartikan jasa sebagai setiap tindakan atau kinerja yang ditawarkan oleh satu pihak pada pihak yang lainnya yang secara prinsip tidak berwujud dan tidak menyebabkan kepindahan kepemilikan. ${ }^{11}$ Karakteristik jasa dapat diartikan sebagai berikut:

a. Tidak berwujud (intangible), sehingga konsumen tidak dapat melihat, mencium, meraba, mendengar dan merasakan sebelum mereka membelinya.

b. Tidak terpisahkan (inseparability), yakni jasa tidak dapat dipisahkan dari sumbernya.

c. Bervariasi (variability) di mana jasa seringkali berubah-rubah tergantung siapa, kapan dan di mana penyajiannya.

d. Mudah musnah (perishability), tidak dapat dijual pada masa yang akan datang.

e. Jasa tidak dapat disimpan dan dikonsumsi pada saat dihasilkan.

f. Konsumen merupakan bagian internal dari proses produksi jasa.

g. Setiap orang atau apapun yang ikut berhubungan dengan konsumen mempunyai andil dalam memberika peranan.

h. Karyawan penghubung merupakan bagian dari proses produksi jasa.

i. Kualitas jasa tidak dapat diperbaiki pada saat proses produksi karena produksi jasa terjadi secara real time. ${ }^{12}$

\footnotetext{
${ }^{10}$ Sutisna, Perilaku Konsumen dan Komunikasi Pemasaran, Bandung: PT Remaja Rosdakarya Offset, Cet 3, 2003, h. 332.

${ }^{11}$ Kotler, Philip. Marketing Management International Edition, New Jersey: Prentice Hall Inc, 2003, h. 428 .

${ }^{12}$ Machali, Imam dan Ara Hidayat, The Handbook of Education Management. Yogyakarta: Magister Pendidikan Islam Universitas Islam Negeri Sunan Kalijaga, 2015, h. 397.
} 
Melihat begitu kompleksnya karakteristik produk jasa mengakibatkan munculnya berbagai macam persoalan yang dihadapi dalam pemasaran jasa. Menurut Philip Kotler dan Paul N Bloom dalam buku Teknik dan Strategi Memasarkan Jasa Profesional, ada 10 masalah khas dalam memasarkan jasa:

a. Tanggung gugat (tanggung jawab) pada pihak ketiga. Dalam memasarkan produk jasa, bukan hanya tentang cara menarik minat dan memuaskan pelangan semata. Tapi juga bagaimana pihak ketiga di luar konsumen memberikan tanggapan atas program pemasaran yang dilakukan oleh lembaga. Sifatnya berhubungan dengan konsekwensi hukum serta etika. Pengelola jasa harus sadar, bahwa melayani satu pelanggan sejatinya juga melayani "client" pihak ketiga yang terkait dengan usahanya. Sistem pemasaran yang hanya mengacu pada kepentingan pelanggan dan keuntungan usaha sendiri tanpa mengindahkan tanggung gugat pihak ketiga bisa berakibat tidak baik yaitu hilangnya kepercayaan dan dicabutnya izin profesi (izin usaha).

b. Ketidakpastian Pelanggan. Masalah kedua yang harus dipertimbangkan dalam marketing jasa adalah terkait karakteristik jasa. Dimana seperti sudah dijelaskan dalam pembahasan sebelumnya, penawaran produk jasa tidak bisa dinilai sebelum konsumen membelinya. Bahkan untuk jenis jasa profesional tertentu, pelanggan tidak bisa mendapat kepastian apakah jasa yang digunakan memberikan hasil sesuai yang diinginkan atau tidak. Hal-hal penuh ketidakpastian seperti ini yang harus dijelaskan oleh seorang pemasar dalam memasarkan jasanya. Intinya, berikan pengertian pada calon konsumen sehingga tidak terjadi komplain atau masalah setelah mereka memutuskan memakai jasa yang ditawarkan.

c. Faktor Pengalaman. Terkait masalah bagian b, meskipun tidak ada kepastian, pembeli jasa biasanya punya bahan pertimbangan yang digunakan dalam memilih jasa yaitu: pengalaman. Calon pelanggan cenderung memilih penyedia jasa yang punya pengalaman sebelumnya di situasi yang sama. Faktor inilah yang harus dipertimbangkan, terutama bagi penyedia jasa baru yang belum punya nama. Maka, pembuktian kualitas pada segelintir pelanggan mutlak harus dijaga. Memang butuh proses panjang. Tapi itulah tantangan dan konsekwensi bisnis yang baru mulai jalan, apapun bentuk bisnisnya. 
d. Keterbatasan Lingkup Pelayanan. hilip Kotler menyebut point ini dengan istilah "keserbanekaan yang terbatas". Dan mungkin hanya berlaku bagi beberapa jenis jasa profesional saja. Dimana lingkup layanan yang diberikan dibatasi oleh aturan standar sehingga sulit memberikan pelayanan yang berbeda dengan pesaing.

e. Menjaga kendali mutu. Menjaga kendali mutu (kualitas) merupakan tugas dan tantangan berat bagi pemasar jasa pada umumnya. Karena berbeda dengan produk barang jadi dimana mutu produk bisa dikendalikan dengan mesin produksi canggih, tidak demikian dengan produk jasa. Dalam bisnis jasa, peran human services lebih dominan. Situasi menjadi rumit ketika staff marketing telah berhasil meyakinkan pelanggan untuk menggunakan jasa yang ditawarkan, sementara karyawan di bagian lain tidak sejalan. Maka penting bagi sebuah organisasi jasa mempekerjakan pegawai pilihan yang memahami prinsip kerja masing-masing. Semua harus bekerja sama dengan kinerja terbaik. Putusnya salah satu mata rantai pelayanan bisa mempengaruhi penilaian pelanggan secara keseluruhan.

f. Membuat pelaku menjadi penjual. Sebenarnya $\mathrm{Mr}$ Kotler mengasumsikan masalah pemasaran jasa yang keenam ini beraku untuk jasa professional. Dimana menyerahkan tugas pemasaran pada staff saja dalam memasarkan jasa profesional yang ditawarkan bukan langkah yang bijak. Pelaku profesional juga harus ikut berperan dalam penjualan.

g. Menyediakan waktu profesional untuk pemasaran. Masalah ini mungkin lebih banyak terjadi dalam jasa profesioanal yang menerapkan tarif per-jam dalam pelayanannya. Contohnya konsultan, psikolog, motivator dan sejenisnya. Bagi penyedia jasa jenis ini, client hanya membayar untuk waktu layanan yang digunakan. Bukan waktu untuk pemasaran. Masalah seperti inilah yang harus dipertimbangkan. Jadi, mengatur jadwal atau manajemen waktu merupakan hal penting.

h. Tekanan untuk bersikap tanggap saja dan bukan aktif menciptakan kegiatan. Poin ini berkaitan dengan manajemen waktu. Dalam memenuhi permintaan konsumen yang konstan, profesional (baca: penyedia jasa) dituntut mampu menyediakan jasa dalam tempo singkat. Kadang konsumen beranggapan layanan yang dia butuhkan seolah semudah mengucap "sim salabim". Dan ini sering mengacaukan 
jadwal yang telah disusun. Masalah seperti ini sering terjadi. Menjadi dilematis jika "order dadakan" datangnya dari pelanggan kelas elite atau orang yang kita kenal baik. Didahulukan bikin agenda berantakan, ditolak efeknya bisa buruk.

i. Pengaruh iklan tidak diketahui. Pada saat Philip Kotler menulis buku ini, jarang ada perusahaan jasa yang mengiklankan produknya. Karena dianggap baru, maka seberapa besar dampak iklan dalam menaikkan omzet belum jelas. Demikian juga media iklan apa yang sekiranya cocok masih mengambang.

j. Basis pengetahuan pemasaran yang terbatas. Masalah terakhir ini paling fatal jika tidak diatasi. Logikanya, bagaimana bisa memasarkan jika pengetahuan tentang ilmu marketing saja tidak menguasai? Dan inilah salah satu faktor terbesar rontoknya usaha secara umum. Bukan saja berlaku untuk jenis bisnis jasa tapi juga semua bisnis. ${ }^{13}$

Itulah gambaran beberapa masalah yang dapat terjadi pada pemasaran jasa, tidak terkecuali pada pemasaran jasa pendidikan. Dengan mengetahui dan memahami masalahmasalah tersebut, diharapkan menjadi peringatan dini bagi pengelola lembaga pendidikan untuk terus memperhatikan hal-hal yang berhubungan dengan munculnya masalah tersebut. Mengingat kembali pepatah lama, lebih mencegah daripada mengobati.

\section{Brand Image dalam Pemasaran Pendidikan}

Menciptakan brand image yang positif pada lembaga pendidikan terbilang tidak begitu mudah. Bagi pengelola lembaga pendidikan, dituntut untuk mengetahui dan memahami hal-hal yang dapat membentuk brand image pada lembaga pendidikan yang dikelola.Untuk membentuk brand image lembaga pendidikan yang positif di mata konsumen, para pengelola pendidikan harus memahami istilah yang disebut dengan bauran pemasaran.

Dalam pemasaran pendidikan, sangat dibutuhkan adanya bauran pemasaran.Bauran pemasaran dalam konteks pendidikan adalah unsur-unsur yang sangat penting dan dapat dipadukan sedemikian rupa sehingga dapat menghasilkan strategi pemasaran yang dapat digunakan untuk memenangkan persaingan. Bauran pemasaran merupakan alat bagi pemasar yang terdiri atas berbagai unsur suatu program pemasaran yang perlu dipertimbangkan agar implementasi strategi pemasaran dan positioning yang ditetapkan dapat berjalan sukses.Bauran pemasaran terdiri dari $7 \mathrm{P}$ yaitu product, price, place,

\footnotetext{
${ }^{13}$ https://www.bisnisjasa.id/2017/10/10-masalah-dalam-pemasaran-jasa.html.
} 
promotion, people, physical evidence, process. Berikut adalah penjabaran dari tujuh prinsip bauran tersebut:

a. Product (produk)

Kotler mendefnisikan produk sebagai segala sesuatu yang dapat ditawarkan ke pasar untuk memenuhi keinginan atau kebutuhan. Produk dengan kata lain adalah keseluruhan objek atau proses yang memberikan sejumlah nilai kepada konsumen. Dalam konteks jasa pendidikan, produk adalah jasa yang ditawarkan kepada pelanggan berupa reputasi, prospek dan variasi pilihan.Lembaga pendidikan yang mampu memenangkan persaingan jasa pendidikan adalah yang dapat menawarkan reputasi, prospek, mutu pendidikan yang baik, prospek dan peluang yang cerah bagi para siswa untuk menentukan pilihan-pilihan yang diinginkannya.Sedangkan kompetensi lulusan adalah yang kualifkasi kemampuan lulusan yang mencakup sikap, pengetahuan, dan ketrampilan.

b. Price (harga)

Price (harga) adalah sejumlah uang yang harus dibayarkan oleh konsumen untuk mendapatkan suatu produk. Harga dalam konteks jasa pendidikan adalah seluruh biaya yang dikeluarkan untuk mendapatkan jasa pendidikan yang ditawarkan. Elemen harga pendidikan dipertimbangkan mengenai penetapan harga SPP, investasi bangunan, laboratorium dan lain-lain.

c. Place (lokasi)

Lokasi berarti berhubungan dengan dimana perusahaan jasa harus bermarkas dan melakukan aktivitas kegiatannya. Dalam konteks jasa pendidikan madrasah place adalah lokasi sekolah berada. Lokasi sekolah sedikit banyak menjadi prefensi calon pelanggan dalam menentukan pilihannya. Lokasi yang strategis, nyaman dan mudah dijangkau akan menjadi daya tarik tersendiri.

d. Promotion (promosi)

Promosi adalah kegiatan mengkomunikasikan penjualan produk dipasaran yang berhubungan langsung dengan masyarakat. Promosi bertujuan untuk memberikan informasi dan meyakinkan konsumen akan manfaat produk yang dihasilkan. Kegiatan promosi yang dapat dilakukan adalah dengan cara advertising melalui media TV, radio, surat kabar, buletin, dan lain-lain. Promosi penjualan juga dapat dilakukakan melalui pameran pendidikan, bazar pendidikan dan investasi, 
melakukan kontak langsung dengan siswa dan juga melakukan kegiatan hubungan dengan masyarakat.

e. People (orang)

People dalam konteks pendidikan adalah orang-orang yang terlibat dalam proses penyamaian jasa pendidikan seperti tata usaha, kepala sekolah, guru dan karyawan. Sumber daya pendidik dan kependidikan ini sangat penting bahkan menjadi ujung tombak dalam proses pemberian layanan pendidikan kepada para siswa dalam lembaga madrasah.

f. Physical Evendence (bukti fsik)

Physical evidence (bukti fsik) adalah lingkungan fsik tempat jasa diciptakan dan langsung berinteraksi dengan konsumennya.Terdapat dua macam bukti fisik yakni, pertama merupakan keputusan-keputusan yang dibuat oleh pemberi jasa mengenai desain dan tata letak gedung seperti desain kelas, gedung sekolah, perpustakaan, lapangan olahraga dan lain-lain. Kedua, bukti pendukung merupakan nilai tambah yang bila berdiri sendiri tidak akan berdiri sendiri dan memiliki peran yang sangat penting dalam proses jasa seperti raport, catatan siswa dan lain-lain.

g. Process (proses)

Proses adalah prosedur atau mekanisme dalam rangkaian aktivitas untuk menyampaikan jasa dari produsen ke konsumen. Dalam konteks jasa pendidikan proses adalah proses pendidikan yang mendukung terselanggaranya proses kegiatan belajar mengajar guna terbentuknya produk/lulusan yang diinginkan. ${ }^{14}$

Langkah-langkah strategis pemasaran jasa pendidikan di lembaga pendidikan:

a. Identifkasi Pasar. Yakni mengidentifkasi dan menganalisis pasar untuk mengetahui kondisi dan ekspektasi pasar termasuk atribut-atribut pendidikan yang menjadi kepentingan konsumen pendidikan. Dalam hal ini sesungguhnnya madrasah memiliki potensi yang tinggi dalam upaya ikut mencerdaskan bangsa dan mensukseskan program wajib belajar nasional.

b. Segmentasi Pasar dan Positioning. Segmentasi pasar membagi pasar menjadi kelompok pembeli yang dibedakan menjadi kelompok pembeli, karakteristik, atau tingkah laku yang mungkin membutuhkan produk yang berbeda. Sedangkan

\footnotetext{
${ }^{14}$ Op. Cit., Imam Machali, 2015, h. 408-412.
} 
positioning adalah karakteristik dan pembedaan produk yang nyata yang memudahkan konsumen untuk membedakan produk jasa antara satu lembaga dengan lembaga yang lain.

c. Diferensiasi Produk. Melakukan diferensiasi merupakan cara yang efektif dalam mencari perhatian pasar. Diferensiasi merupakan salah satu dari tiga strategi pemasaran sebagai strategi bersaing yaitu: 1) Diferensiasi yakni melakukan penawaran yang berbeda dibandingkan penawaran competitor. 2) Keunggulan biaya yakni strategi mengefsienkan seluruh biaya produksi atau jasa sehingga bisa dijua lebih murah dibanding pesaing. 3) Fokus yakni strategi menggarap satu target khusus.

d. Komunikasi pemasaran. Sekolah sebagai lembaga ilmiah akan lebih elegan apabila bentuk-bentuk komunikasi disajikan dalam format ilmiah. Seperti menyelenggrakan kompetisi bidang studi, seminar, dan yang paling efektif adalah publikasi prestasi oleh media independen seperti berita dalam media massa.

e. Pelayanan sekolah. Pelayanan sekolah terlihat sebagai apa yang diharapkan konsumen. Kesenjangan yang sering terjadi adalah adanya perbedaan persepsi kualitas maupun atribut jasa pendidikan. ${ }^{15}$

Apa yang telah dipaparkan di atas merupakan hal-hal yang perlu diperhatikan dalam membangun brand image pada lembaga pendidikan, kususnya dalam rangka pemasaran pendidikan. Dengan memperhatikan hal-hal tersebut diharapkan lembaga pendidikan yang kurang mampu bersaing dapat segera bersaing dengan lembaga-lembaga pendidikan lainnya yang telah eksis dan mengambil bagian dalam persaingan pendidikan di Indonesia bahkan hingga ke tingkat Internasional.

\section{KESIMPULAN}

Berdasarkan uraian di atas dapat disimpulkan bahwa membangun sebuah brand image lembaga pendidikan yang positif dalam rangka pemasaran pendidikan yang lebih baik, tidaklah mudah.Namun hal tersebut, tidak berarti bahwa hanya beberapa lembaga pendidikan tertentu dapat membangun dan menciptakan brand image yang positif bagi masyarakat. Tidak menutup kemungkinan dengan mempelajari berbagai teori membangun

${ }^{15}$ Afdatun Khasanah, Pemasaran Jasa Pendidikan Sebagai Strategi Peningkatan Mutu Di Sd Alam Baturraden, Jurnal el-Tarbawi, Volume 8, No. 2, 2016. 
brand image yang telah dijelaskan sebelumnya dapat membantu lembaga-lembaga pendidikan lainnya yang masih dalam kondisi tertinggal, mampu turut serta dalam persaingan pemasaran pendidikan. Dimana pemasaran pendidikan yang dimaksud bukanlah komersialisasi lembaga pendidikan, namun lebih kepada persaingan mutu layanan lembaga pendidikan bagi masyarakat.

\section{DAFTAR RUJUKAN}

Abdul Hadis, Nurhayati B, Manajemen Mutu Pendidikan, Bandung: Alfabeta, 2010.

Afdatun Khasanah, Pemasaran Jasa Pendidikan Sebagai Strategi Peningkatan Mutu Di Sd Alam Baturraden, Jurnal el-Tarbawi, Volume 8, No. 2, 2016.

Andi Sadat, Brand Belief : Strategi Membangun Merek Berbasis Keyaninan, Jakarta: Salemba Empat, 2009.

Arbangki, Dakir, Umiarso, Manajemen Mutu Pendidikan, 2016, Jakarta: Prenadamedia

Hermawan kartajaya, Hermawan Kartajaya On Brand Seri 9 Elemen Marketing, Bandung: Penerbit Mizan, 2007.

https://www.bisnisjasa.id/2017/10/10-masalah-dalam-pemasaran-jasa.html.

Levitt, The Marketing Imagenation, London: The Free Press, 1983.

Machali, Imam dan Ara Hidayat, The Handbook of Education Management. Yogyakarta: Magister Pendidikan Islam Universitas Islam Negeri Sunan Kalijaga, 2015.

Nanang Fattah, Ekonomi dan Pembiayaan Pendidikan, Bandung: Remaja Rosda Karya, 2000.

Philip Kotler, Manajemen Pemasaran, Edisi Milenium, Jakarta: PT. Prehellindo, 2002.

Priyono, Manajemen Sumber Daya Manusia, Jakarta: Zifatama Publisher, 2010.

Sri Minarti, Manajemen Sekolah: Mengelola Lembaga Pendidikan Secara Mandiri, Jogjakarta: Ar-Ruzz Media, 2011.

Susanto, Himawan Wijarnako, Power Branding (Membangun Merek Unggul Dan Organisasi Pendukungnya Jakarta:PT.MizanPublika,2004.

Sutisna, Perilaku Konsumen Dan Komunikasi Pemasaran, Bandung: PT Remaja Rosdakarya Offset, Cet 3, 2003. 